\title{
CTSL wt Allele
}

National Cancer Institute

\section{Source}

National Cancer Institute. CTSL wt Allele. NCI Thesaurus. Code C49710.

Human CTSL wild-type allele is located within $9 q 21-q 22$ and is approximately $5 \mathrm{~kb}$ in length. This allele, which encodes cathepsin L protein, is involved in lysosomal protein degradation. 